\title{
Cultural Hybridity and Depiction of Bengali Culture in Jhumpa Lahiri's The Namesake
}

Dr. Soma Guha Das*

Assistant Professor, Dept. of English St.Aloysius' College Jabalpur, India

\section{*Corresponding Author}

Dr. Soma Guha Das

\section{Article History}

Received: 11.05.2020

Accepted: 19.05.2020

Published: 07.06.2020

\begin{abstract}
Post colonial writers attempted to portray the social and political milieu in their works. They depict the nonconventional themes which have broken the pre-occupied age- old tradition established by the writers since Vedic period. Writers started writing on East-West encounter, urban middle class mores, changing patterns of human relationships and slowly their concerns widened. The post- independent era hoists the flag of women's writings with the flavor of real incidents of their life which were often hidden from others. They become the voice of society through the medium of literature. Their accents are loud enough to be heard in the field of Indian English writings as voices of women who could write of experiences of living confined lives. Jhumpa Lahiri herself being an Indian-American, born to Bengali immigrant parents, is able to fictionalize the live and real experiences of immigrant Indians in America. As an eye-witness 'Bengali-American' writer of Indian ancestry, Lahiri is crowned as an International writer among the Commonwealth Writers and has a universal appeal. She explores her character's dilemma, struggles, anxieties and biases to express details of immigrant psychology and behavior. Her characters swing between their native culture and the culture of the host country resulting in their cultural hybridist. The first and second generations play the role of cultural mediators between the adopted culture and the culture of motherland. This paper explores Lahiri's depiction of Bengali culture in The Namesake ranging from the food habits, dress, festivals, rituals, customs, religious ceremonies, music as well as the behavior of the first generation immigrants in America who eagerly strive to transmit them to the second generation individuals.
\end{abstract}

Keywords: Postcolonial, Milieu, Nonconventional, Immigrant, Culture, Transmit.

\section{INTRODUCTION}

The writers of pre-independence India attempted to portray the social and political milieu in their works. The post- independence writers have shown the courage to depict the nonconventional themes which have broken the preoccupied age- old tradition established by the writers since Vedic period. Nineteenth century European imperialism and colonialism had impact over postcolonial global culture. It also combines Eastern and Western thoughts, philosophy, history, economy, literary studies, politics and social structure. Postcolonial literature can be defined as literature which is written by colonized and formerly colonized peoples in various languages. Post-independence era witnessed writers adopting socially relevant themes and socialistic approaches. Writers started writing on East-West encounter, urban middle class mores, changing patterns of human relationships and slowly their concerns widened. Heterogeneity, multiplicity and particularly, exile in one's own land or a foreign wanderer in other country are the distinct elements of postcolonial writings especially in multicultural set-up. The post- independent era hoists the flag of women's writings with the flavor of real incidents of their life which were often hidden from others. They become the voice of society through the medium of literature. This definitely has a leading role in building the Indian woman at a decisive phase where she stands at a new threshold to redefine herself with the family as well as society.

Copyright @ 2020: This is an open-access article distributed under the terms of the Creative Commons Attribution license which permits unrestricted use, distribution, and reproduction in any medium for non commercial use (NonCommercial, or CC-BY-NC) provided the original author and source are credited. 
Post -Independence Indian women writers also ensured their presence as contributors to the corpus of Indian literature. Their accents are loud enough to be heard in the field of Indian English writings as voices of women who could write of experiences of living confined lives. Jhumpa Lahiri herself being an Indian-American, born to Bengali immigrant parents, is able to fictionalize the live and real experiences of immigrant Indians in America. As an eyewitness 'Bengali-American' writer of Indian ancestry, Lahiri is crowned as an International writer among the Commonwealth Writers and has a universal appeal. Jhumpa Lahiri stole the heart of every Indian by winning the Pulitzer Prize for Fiction 2000 with her debut collection of short stories Interpreter of Maladies: Stories of Bengal, Boston and Beyond, has created an important place not only in the world of fiction with her sought after novel. Jhumpa Lahiri, the daughter of Bengali middle class Indian immigrants moved to the US along with her family when she was three years old. Lahiri's mother wanted her daughters to grow up knowing their own Bengali tradition and culture, the family often visited grandparent's house in Calcutta. Lahiri's writing depicts her own experiences as well as those of her parents, relatives, acquaintances and others in the Bengali communities. She explores her character's dilemma, struggles, anxieties and biases to express details of immigrant psychology and behavior. Her characters swing between their native culture and the culture of the host country resulting in their cultural hybridist.

'Cultural hybridity' means the association of individuals belonging to different cultures and their plea to adjust themselves with others belonging to the culture other than their own. In this process immigrants face the crisis of dual identities, cultural dilemma, and fear the loss of their identity while struggling to assimilate in the multicultural society. The first and second generations play the role of cultural mediators between the adopted culture and the culture of motherland. This paper explores Lahiri's depiction of Bengali culture in The Namesake ranging from the food habits, dress, festivals, rituals, customs, religious ceremonies, music as well as the behavior of the first generation immigrants in America who eagerly strive to transmit them to the second generation individuals.

Jhumpa Lahiri portrays Ashima and Ashoke Ganguli as the first generation couple who gets married when Ashoke is pursuing doctorate in Electrical engineering at MIT, US. After becoming pregnant, barely two weeks remain for her delivery, she relishes the concoction of Rice crispies combined with peanuts, chopped red onion, salt, lemon juice, thin slices of green chilli and mustard oil - a Bengali "snacks sold for pennies on Calcutta sidewalks and on railway platforms throughout India, spilling rom newspaper cones" (Lahiri 1). When Ashima feels a terrible pain in her abdomen, she calls out her husband Ashoke but does not say his name. It is a custom in Bengal not to call husband by his name. Therefore, Ashima utters the interrogative in Bengali language which translates as "Are you listening to me?" (Lahiri 2). Ashima is taken to

Mount Auburn Hospital by a taxi where she is instructed to remove her Murshidabad silk sari and asked to wear a cotton gown which to her embarrassment only reaches her knees. When the obstetrician Dr. Ashley tells her after checking-up that labour can take twenty hours or more, she becomes sad since there is nobody to console her at this difficult hour. She feels alone on this foreign soil. She remembers the Indian tradition of daughter going to her parent's house on her first delivery. But in America, she is disturbed at the thought of delivering the baby " so far from home, unmonitored and unobserved by those she loved"(Lahiri 6). She is going through the tattered copy of Desh magazine which she had brought to read on her plane ride to Boston. Though she has read it several times, but she does not want to throw it away simply because "the printing pages of Bengali type are a perpetual comfort to her"(Lahiri 6).

When the child is born in the morning without presence of a single grandparent or relative, Ashima pities her son as " he has never known of a person entering the world so alone, so deprived" (25). Since she belonged to a joint family in which she brought up and was always surrounded by many relatives but in America, she is feeling lonely and detached. Thoughts of raising her child alone in a foreign country makes her feel more sorrowful. She emphatically begs her husband," I want to go back"(33). But it is not possible for Ashok to abide by his wife's wishes as he is pursuing his studies in this foreign land.

Immediate after the child's birth, Ashima eagerly waits for a letter from her grandmother writing the name of the child. Though the grand mother has mailed the letter containing one name for a girl, one for a boy a month ago , it does not reach America. In India parents take their own time in naming a child. But in America, the child has to be given a name before he is released from the hospital. So the problem of selecting the name of the child arises for Ashima and Ashoke. Mr. Wilcox, the compiler of hospital birth certificates informs the couple that in America, a baby cannot be released without issuing a birth certificate and " that a birth certificate needs a name"(27). He suggests to the couple to name their child after one of their ancestors. But this is not a Indian tradition as Lahiri notices "This sign of respect in America and Europe, this symbol of heritage and lineage, would be ridiculed in India" (28).

Suddenly Ashoke remembers the train accident he met many years ago and the way he was rescued with a page of Russian author Nikolai Gogol's book of short stories crumpled in his fingers. Since the author of this book helped him to save his life, he has great respect for him. Therefore, he suggests the name "Gogol"for his son with the concern of 
Ashima and it is registered in the hospital's files of Boston. Gogol would be the daknam (pet name) and parents would think of bhalonam (good name). It is significant in Bengali culture that each person has two names, family, friends and inmates at home call children by their pet names. Even Ashima and Ashoke have pet names -Monu and Mithu respectively. Good name is written for the identification in the outside world; it appears on "envelopes, on diplomas, in telephone directories and in all other public places"(26).

The "Annaprashan" is a ritual in Bengali culture to celebrate an infant's first eating of food other than milk when the baby is six month old. In this ceremony the mother prepares a variety of food specially payesh, a dish made up of milk, sugar and rice. Mama (mother's brother) feeds the child a spoonful of the payesh for the first time. Then the child is asked to touch the objects as gold (a symbol of wealth), a book (Education), a pen ( a symbol of career), soil (property) which are kept in a plate. Among all whatever the child touches, predicts his/her future. There is no Baptism or naming ceremony in Bengali culture. When Gogol's annaprasan is conducted he is dressed " an infant Bengali groom, in a pale yellow pajama punjabi from his grandmother in Calcutta" (39). The food is arranged in ten small bowls. "Ashima regrets that the plate on which the rice is heaped is melamine, not silver or brass or at the very least stainless steel"( 39).when the feeding ceremony begins a handful of women start ululating the tradition, typical of Bengal. The child is given payesh three times. Then he is offered a plate"holding a clump of cold Cambridge soil dug up from the backyard, a ballpoint pen and a dollar bill to see if he will be a landowner, scholar or businessman"(40). But Gogol does not touch anything. Celebration of Annaprashan Ceremony in America gives great importance for Ashoke and Ashima because such ceremony means a lot for them in a foreign land.

Ashima is deeply rooted in her culture and strict to practice Bengali culture and tradition at home. As an Indian mother she is ready to sacrifice everything for her children. Ashima loves to wear Indian costume as sari, cooks Indian food and takes care to keep her household meticulous, though Ashoke wears dress like American. After growing up her children, she becomes more flexible and practices new things. She arranges several parties on several festivals like Durga pujo at her home, calls Bengali friends, serve them typical Bengali food and try to preserve the cultural identityof her Bengali family. During these parties, the Bengali people, sitting on the floor, play various games of cards, sings songs of Rabindranath Tagore and Nazrul as they create an atmosphere replete with Indianness. Fieldhouse rightly suggests, "Food habits are an integral part of cultural behavior and are often closely identified with particular groups" (Fieldhouse :41) on fourteenth birthday,Ashima throws a party conforming to the Bengali cultural identity. She makes "lamb curry with lots of potatoes, luchis, thick channa dal with swollen brown raisins, pineapple chutney, sandeshes molded out of saffron-tinted ricotta cheese" (72). Gogol's school friends are also invited on this occasion, Ashima finds it very stressful to feed " a handful of American children, half of whom always claim they are allergic to milk, all of whom refuse to eat the crust of their bread" (72). For the sake of her children Ashima celebrates "the Birth of Christ, an event the children look forward to far more than the worship of Durga and Saraswati" (64). Once in a week, Ashima makes American food for the sake of Gogol" Shake'n Bake chicken or Hamburger Helper prepared with ground lamb” (65).In this foreign land, Ashima has become a cultural hybrid struggling to maintain her cultural traditions and trying to adopt the American lifestyle for the happiness of her children. After the death of her husband, Ashima decides to stay for six months in India and another six months in America. Ashima recalls when she first stepped in America, she missed her own country as she now missed America after shifting to India For Ashima both Indian and American homes becomes alien to her. During her life of thirty-three years in America, she missed her life in India, she misses her American-life living in India.

Gogol is an American born Bengali-child and not ease with Bengali culture though his parents try to acculturate him with it. The only way to learn mother-tongue is to converse in Bengali, therefore, they speak to him in Bengali at home as they are of opinion that their son will be able to learn the language of the host country when he comes out from the home. Ashoke enrolls Gogol as Nikhil Ganguly in the school. But Gogol does not wish to have a new name. he is "afraid to be Nikhil, someone he does not know"(57). As Bengali have two names, pet name and bhalonam his father consoles him saying "Don't worry to me and your mother, you will never be anyone but Gogol” (57). When Gogol is in third grade, his parents send to learn Bengali language every other Saturday at their friend's house, but Gogol does not like it because he misses the Saturday morning drawing class with his American classmates. Gogol's attitude towards the culture of his parents and that of his American school mates and teachers make him a cultural hybrid Indi- American hovering between speaking Bengali at home and English at school, having American food like hamburgers at school and Indian food like rice, dal and fish at home. He is considered by American as "ABCD- American Born Confused Desi" though he considers himself an American, the American society says, "But you're Indian" (157). Gogol has an affair with Ruth and Maxine but he does not want them to introduce his parents. He strives to be American but he fails to eradicate Gogol. But the death of his father changes his life as he understands that he cannot abandon the importance of either of the cultures - American and Indian but definitely try to fuse the two. He feels " a sudden reconnect with lost Bengali rituals; this desire to return culminates in marriage to an Indian American woman (Moushumi)"(Friedman 115). After so many years, Gogol had learned that "it was a Bengali son's duty to shave in the wake of a parent's death" (179). All the religious rituals were done by Gogol after his father's death. Immediate aftyer the eleven days of mourning, Gogol breaks up with his American girl friend Maxine Ratcliff and decides to marry Moushumi, chosen by his family. 
The arranged marriage happens to bind Gogol and Moushumi together as a Bengali couple to ensure the promotion of Bengali culture. But after a short while, Moushumi starts an affair with a French man. When Gogol comes to know about it, it is " for the first time in his life, [that] another man's name upset Gogol more than his own" (283). Gogol and Moushumi are separated. Now Gogol is thirty-two years old, already married and divorced"(284). Lahiri has shared the incessant struggle of Gogol, a man of cultural hybridity trying to find solace by experimenting with various American lifestyle and at the same time, trying to adopt Bengali culture practiced at house. The end of the novel reminds the beginning of the life of Gogol when in isolation, he remembers the moments spent with his father who is now no more and begins reading the book The short Stories of Nikolai Gogol gifted on his fourteenth birthday by him.

Though Jhumpa Lahiri belongs to second generation American, she has the first hand experience of Indian culture, Bengali language and Bengali locale. Though the character of Gogol, Lahiri has revealed her own quest of identity and cultural hybridity. Children learn mother tongue from their parents, they get integrated to the standard American culture by schooling, university education and other extracurricular activities fundamental to American culture. They are caught between two conflicting realities - one of the host countries through the socio- cultural surroundings and the other own country of their parents. In this process, they get entangled between their native culture and foreign culture resulting in cultural hybridity. Lahiri points out that Gogol and Sonia are more American than Ashoke and Sonia with respect to the language spoken and their behavior pattern.

\section{Work Cited}

1. Lahiri, J.(2011). The Namesake, London: Harper Collins, Tenth Impression.

2. Fieldhouse, P. (1986). Food and Nutrition: Customs and Culture. London: Taylor \& Francis, 1986. Print.

3. Friedman, N. (2008). From Hybrids to Tourists: Children of Immigrants in Jhumpa Lahiri's The Namesake. Critique: Studies in Contemporary Fiction, 50(1), 111-128. 